\title{
1 Multiple Palaeoproterozoic Carbon Burial Episodes and Excursions
}

2

3 A. P. Martin ${ }^{\mathrm{a}, \mathrm{b}}$, A. R. Prave ${ }^{\text {c }}$, D. J. Condon ${ }^{\mathrm{a}}$, A. Lepland, ${ }^{\mathrm{d}, \mathrm{e}}$, A. E. Fallick ${ }^{\mathrm{g}}$, A. E. Romashkin ${ }^{\mathrm{h}}$, P. V. 4 Medvedev $^{\text {h }}$, D. V. Rychanchik ${ }^{\text {h }}$

5

6

${ }^{\text {a }}$ NERC Isotope Geosciences Laboratory, British Geological Survey, Keyworth, UK. NG12 5GG

$7 \quad{ }^{b}$ Present address: GNS Science, Private Bag 1930, Dunedin, New Zealand

$8{ }^{c}$ Department of Earth and Environmental Sciences, University of St Andrews, St Andrews, KY16 9AL, 9 Scotland, $U K$

${ }^{d}$ Geological Survey of Norway, Postboks 6315 Sluppen, 7491 Trondheim, Norway

${ }^{e}$ Tallinn Technical University, Institute of Geology, 19086 Tallinn, Estonia

${ }^{f}$ Centre for Arctic Gas Hydrate, Environment and Climate, University of Troms $\phi, 9037$ Troms $\phi$,

Norway

${ }^{g}$ Scottish Universities Environmental Research Centre, East Kilbride, Glasgow G75 0QF, Scotland,

${ }^{h}$ Institute of Geology, Karelian research Centre, Russian Academy of Science, Petrozavodsk, Russia

* Corresponding Author. E-mail address: a.martin@gns.cri.nz (A.P. Martin)

\section{Keywords}

Carbon Burial Event; GOE; Shunga-Francevillian Event; Lomagundi-Jatuli Event; U-Pb 
29 Highlights

30 - Palaeoproterozoic carbon burial episodes (CBE) \& excursions are temporally discrete

31 - Zircon ID-TIMS yields Russian CBE ages at c. 1.97 (Onega) and c. 1.92 Ga (Pechenga)

32 - There is a temporal relationship between Large Igneous Provinces and CBE

33 - Similarities noted between Palaeoproterozoic CBE and Mesozoic Ocean Anoxic Events

34 - We suggest biogeochemical processes analogous to modern ones post the GOE

35

36

37 


\section{ABSTRACT}

Organic-rich rocks (averaging 2-5\% total organic carbon) and positive carbonate-carbon isotope excursions $\left(\delta^{13} \mathrm{C}>+5 \%\right.$ and locally much higher, i.e. the Lomagundi-Jatuli Event) are hallmark features of Palaeoproterozoic successions and are assumed to archive a global event of unique environmental conditions following the c. 2.3 Ga Great Oxidation Event. Here we combine new and published geochronology that shows that the main Palaeoproterozoic carbon burial episodes (CBEs) preserved in Russia, Gabon and Australia were temporally discrete depositional events between c. 2.10 and $1.85 \mathrm{Ga}$. In northwest Russia we can also show that timing of the termination of the Lomagundi-Jatuli Event may have differed by up to 50 Ma between localities, and that $\mathrm{Ni}$ mineralisation occurred at c. 1920 Ma. Further, CBEs have traits in common with Mesozoic Oceanic Anoxic Events (OAEs); both are exceptionally organic-rich relative to encasing strata, associated with contemporaneous igneous activity and marked by organic carbon isotope profiles that exhibit a stepped decrease followed by a stabilisation period and recovery. Although CBE strata are thicker and of greater duration than OAEs (100s of metres versus metres, $\sim 10^{6}$ years versus $\sim 10^{5}$ years), their shared characteristics hint at a commonality of cause(s) and feedbacks. This suggests that CBEs represent processes that can be either basin-specific or global in nature and a combination of circumstances that are not unique to the Palaeoproterozoic. Our findings urge circumspection and reconsideration of models that assume CBEs are a Deep Time singularity. 


\section{Introduction}

The Palaeoproterozoic Era (2.5-1.6 Ga) was one of the most remarkable in Earth history: the Great Oxidation Event (GOE; Canfield, 2005), global scale glaciations (Young, 2004), deposition of the first significant phosphorites (Lepland et al., 2014; Papineau, 2010), interruption in iron formation deposition (Bekker et al., 2010; Isley and Abbott, 1999), widespread metallogenesis (Hoatson et al., 2006) and unprecedented fluctuations in the global carbon cycle marked firstly by the largemagnitude Lomagundi-Jatuli Event positive C-isotope excursion (Karhu and Holland, 1996; Martin et al., 2013a) and then by deposition of organic-rich sedimentary rocks (Melezhik et al., 1999) termed the Shunga-Francevillian Event (Kump et al., 2011). The latter two events have been implicated as key influences on atmospheric oxygen levels following the GOE and a key assumption has been that each was a response to mechanisms operating more-or-less synchronously and globally: an initial worldwide increase in nutrient fluxes enhanced biological productivity and carbon burial thereby increasing free $\mathrm{O}_{2}$ (Bekker and Holland, 2012), then subsequent exposure and weathering of the organic-rich units resulted in global $\mathrm{O}_{2}$ drawdown, with consequent marine anoxia and euxinia.

Precisely constraining the timing of isotopic excursions in Palaeoproterozoic sedimentary sections is an ongoing challenge for geochronology (Martin et al., 2013a). Here we provide nine new age constraints on Palaeoproterozoic sections from the upper Pechenga Greenstone Belt (Pechenga) and Onega Basin in NW Russia using single grain zircon and baddeleyite dating by the high precision isotope dilution thermal ionisation mass spectrometry (ID-TIMS) method. These data were the end result after first analysing 953 zircon grains from 73 samples by laser ablation-inductively coupled plasma mass spectrometry (LA-ICPMS). Comparing our data with published age constraints from NW Russia, Gabon and Australia we assess the age constraints and synchronicity of CBEs and the Lomagundi-Jatuli Event as well as the age constraints to Ni mineralisation in Pechenga.

\section{Geological Setting}


84 Our new data pertain specifically to Pechenga and Onega Basins (Fig 1) in the Russian portion of the 85 Fennoscandian Shield (comprehensively reviewed by Melezhik et al., 2013). The former consists of 86 the North Pechenga Group (Fig. 2), with four pairs of sedimentary- (c. $1.5 \mathrm{~km}$ in composite total 87 thickness) and volcanic-dominated formations (c. $6.5 \mathrm{~km}$ in composite total thickness), that sits unconformably on Archaean basement and is overthrust by the South Pechenga Group. The Onega Basin is a c. $3 \mathrm{~km}$-thick succession that rests unconformably on Archaean rocks and is comprised of subordinate siliciclastic and carbonate rocks and mafic igneous rocks that are voluminous locally (Fig. 3). Both successions were variably deformed and metamorphosed (prehnite-pumpellyite to amphibolite facies) during the c. 1.9-1.8 Ga Sveconfennian Orogeny (Melezhik et al., 2013), with the samples in this study experiencing up to greenschist facies metamorphism.

Organic-rich rocks (total organic carbon content $2-5 \%$, commonly $>10 \%$ and in exceptional instances as much as 98\%) are found in the Pilgujärvi Sedimentary Formation in the North Pechenga Group and the Zaonega Formation in the Onega Basin. The latter is a type section of the Shunga Event (Shunga village, Karelia; Kump et al., 2011; Melezhik et al., 1999). The Zaonega Formation and underlying Tulomozero Formation have carbonate-carbon isotope values up to $+10 \%$ and +17.2 \%o (all values relative to Vienna Pee Dee Belemnite), respectively (Kump et al., 2011; Melezhik et al., 1999), and are considered part of the Lomagundi-Jatuli Event (e.g. Martin et al., 2013a). In the Pechenga Greenstone belt, the Kuetsjärvi Sedimentary Formation has $\delta^{13} \mathrm{C}$ values up to $+9 \%$ and is also linked to the Lomagundi-Jatuli Event (Melezhik et al., 2013). It is overlain by the Pilgujärvi Sedimentary Formation (turbiditic sandstone and shale with contemporaneous mafic and ferropicritic volcanic rocks and crosscutting gabbroic and gabbro-wehrlite intrusions; many are rich in Ni-sulphide ores termed the Productive Formation) and Volcanic Formation of pillowed and massive tholeiitic volcanic rocks, with one conspicuous c. 50 m thick felsic interval (Melezhik et al., 2013). 
109 The $2505 \pm 1.6 \mathrm{Ma}$ General'skaya intrusion $\left({ }^{207} \mathrm{~Pb} /{ }^{206} \mathrm{~Pb}\right.$ ID-TIMS zircon age; Amelin et al., 1995)

110 crosscuts Archaean basement and is overlain by the Pechenga succession (Fig. 2). Detrital zircons in

111 the Neverskrukk Formation are c. 2400 Ma (LA-ICPMS; Gärtner et al., 2014) and those in the

112 Kolosjoki Sedimentary Formation (sourced from the underlying Kuetsjärvi Volcanic Formation) yield

113 concordant ${ }^{207} \mathrm{~Pb} /{ }^{206} \mathrm{~Pb}$ ages from two stratigraphic intervals at $2049 \pm 28 \mathrm{Ma}$ [dated by the secondary

114 ion mass spectrometry (SIMS) method] and $2058 \pm 2$ Ma (ID-TIMS; Melezhik et al., 2007). Zircons

115 from a tuff in the Kolosjoki Sedimentary Formation yield a concordant ${ }^{207} \mathrm{~Pb} /{ }^{206} \mathrm{~Pb}$ ID-TIMS age at

$1162056.6 \pm 0.8 \mathrm{Ma}$ : this date is interpreted as marking the termination of the Lomagundi-Jatuli Event

117 (Martin et al., 2013b). The upper part of the Kolosjoki Sedimentary Formation yields detrital zircons

118 dated at $1916 \pm 1$ Ma (ID-TIMS; Gärtner et al., 2011). Two clinopyroxene fractions from a Pilgujärvi

119 ferropicritic intrusion yield a Sm-Nd whole rock isochron at $1990 \pm 66 \mathrm{Ma}$ (Hanski et al., 1990).

120 Pilgujärvi intrusions also scatter about a $1980 \mathrm{Ma}$ Re-Os isochron (error $\pm 40 \mathrm{Ma}$ estimated; Walker

121 et al., 1997) whereas Pilgujärvi organic-rich shale and sulphidic layers yield a Re-Os isochron age at

$1222004 \pm 9 \mathrm{Ma}(\mathrm{MSWD}=7 ; \mathrm{n}=7)$, with a scatter of model ages between 1926 and $2231 \mathrm{Ma}($ Hannah

123 et al., 2006). Zircon grains from a felsic tuff in the Pilgujärvi Volcanic Formation have yielded a

124 maximum ${ }^{207} \mathrm{~Pb} /{ }^{206} \mathrm{~Pb}$ age at $1988 \pm 3 \mathrm{Ma}$ (SIMS; $\mathrm{n}=10$; Hanski et al., 2014). An upper intercept

$125{ }^{207} \mathrm{~Pb} /{ }^{206} \mathrm{~Pb}$ zircon age at $1918 \pm 3 \mathrm{Ma}$ (ID-TIMS; Skuf'in and Bayanova, 2006) has been derived from

126 four discordant fractions separated from a Fe-rich gabbro-dolerite volcanic neck, inferred to be

127 comagmatic with, and the intrusive equivalent of the Pilgujärvi Volcanic Formation. The Pilgujärvi

128 gabbroic intrusions yield baddeleyite grains at $1980 \pm 10 \mathrm{Ma}$ and discordant zircon grains $(\mathrm{n}=2)$

129 anchored to concordia by an apatite grain $(\mathrm{n}=1)$ yield an age at $1987 \pm 5 \mathrm{Ma}$ (ID-TIMS; Skuf'in and

130 Bayanova, 2006). Skuf'in and Bayanova (2006) have suggested that igneous rocks of the Pilgujärvi

131 formations were erupted and emplaced between c. 2000 and 1900 Ma.

2.2 Existing geochronology for the Onega Basin

The Onega Basin succession rests unconformably on Archaean basement that is crosscut by the 2449 \pm 1.1 Ma Burakovka Pluton (concordant ${ }^{207} \mathrm{~Pb} /{ }^{206} \mathrm{~Pb}$ ID-TIMS zircon age; Amelin et al., 1995). Zircon 
grains in a kimberlite and those from a dolerite, both cross-cutting the Zaonega Formation, yield ages of $1919 \pm 18 \mathrm{Ma}$ (SIMS; $\mathrm{n}=12 ;$ MSWD = 0.81; Priyatkina et al., 2014) and $1956 \pm 5$ Ma age (SIMS; $\mathrm{n}=9$; MSWD $=0.18$; Stepanova et al., 2014), respectively. A concordant ${ }^{207} \mathrm{~Pb} /{ }^{206} \mathrm{~Pb}$ zircon date of $1976 \pm 9$ Ma (SIMS; Puchtel et al., 1998) has been obtained on a lava flow in the topmost part of the Jangozero Formation; note that this unit was originally interpreted as the basal part of the Medvedzhegorsk Formation (after mapping by Negrutsa, 1963, near the town of Medvedzhegorsk c. $60 \mathrm{~km} \mathrm{NE}$ ) but was later correctly re-assigned to the Jangozero Formation (Sivaev et al., 1982). A ReOs isochron of $1969 \pm 18$ Ma was measured from Suisari Formation samples $(\mathrm{n}=18$; whole rock peridotite and gabbro + ilmenite + ulvöspinel; Puchtel et al., 1998) and two Suisari gabbros have individually yielded a Sm-Nd whole rock + clinopyroxene date at $1988 \pm 34 \mathrm{Ma}(\mathrm{MSWD}=1.8 ; \mathrm{n}=$ 13) and a $\mathrm{Pb}-\mathrm{Pb}$ whole rock + clinopyroxene + plagioclase date at $1985 \pm 57 \mathrm{Ma}(\mathrm{MSWD}=3.0 ; \mathrm{n}=$ 18) (Puchtel et al., 1999). A Re-Os isochron for four splits from two core samples of organic-carbonrich siltstone in the Zaonega Formations yields an age of $2.05 \mathrm{Ga}$ (Hannah et al., 2008). In the Tulomozero Formation a $\mathrm{Pb}-\mathrm{Pb}$ carbonate whole rock date has yielded an age at $2090 \pm 70 \mathrm{Ma}$ (Ovchinnikova et al., 2007), suggesting that the age of the Zaonega Formation is greater than 1969 Ma and possibly less than 2050 Ma (Hannah et al., 2010; Hannah et al., 2008; Ovchinnikova et al., 2007).

\section{Methods}

Zircons were isolated from samples using conventional mineral separation techniques at the NERC Isotope Geosciences Laboratory (NIGL), U.K, which keeps a complete log of all samples and it is noteworthy that no samples with the dates reported in this study have been processed in this lab for several years making cross-contamination improbable. A total of 33 samples from Pechenga and 40 samples from Onega Basin were collected and underwent sample separation for heavy minerals (Table S1). All 953 separated zircons were first analysed by LA-ICPMS (Table S2) and the 
161 Palaeoproterozoic-aged sub-set of these were analysed by ID-TIMS (Table S3). A more detailed

162 description of the methods is included in the online supplementary material.

\subsection{Field descriptions and petrography of dated units from Pechenga}

\subsubsection{Kolosjoki Volcanic Formation}

167 Sample Ru6610 (69²7.456 N, 30²4.743 E; all sample locations are given in Fig. S1) was collected from a $2 \mathrm{~m}$ wide dyke with sharp wall-rock contacts. In hand specimen it is a mesocratic, mediumgrained, equigranular rock with crystals of plagioclase and pyroxene. This gabbroic dyke fed the basaltic pillows of the Kolosjoki Volcanic Formation (Fig. 2).

\subsubsection{Pilgujärvi Sedimentary Formation}

172 Sample Ru5410 $\left(69^{\circ} 25.106 \mathrm{~N}, 30^{\circ} 26.357 \mathrm{E}\right)$ is a thin-bedded (beds $\left.1-3 \mathrm{~cm}\right)$ cross-laminated greywacke sandstone collected from outcrop (Fig. 4a). The dark-colour is likely due to abundant volcanic lithics; sulphides are also present.

\subsubsection{Pilgujärvi Volcanic Formation}

Sample Ru5610 $\left(69^{\circ} 24.880 \mathrm{~N}, 30^{\circ} 26.657 \mathrm{E}\right)$ is one of $15,1-6 \mathrm{~cm}$-thick melanocratic tuffs within a 1.5 $\mathrm{m}$ thick interval (Fig. 4b) sandwiched between mafic lava flows approximately $100 \mathrm{~m}$ above the base of the Pilgujärvi Volcanic Formation. The interval was collected in bulk and then cut with a rock saw in the lab in order to sample individual tuff layers. In thin section the 6-cm-thick Ru5610 sample shows unwelded scoria clasts and crystals (euhedral to anhedral - angular) of feldspar, in a finegrained groundmass of feldspar, clinopyroxene and opaques (Fig. 4c). Glass has broken down into clays and carbonate. The preservation of delicate volcanic structures, overall mineralogy, sharp upper and lower contacts and an absence of sedimentary features classify this as a mafic medium tuff (classification after White and Houghton, 2006). 
A c. $50 \mathrm{~m}$-thick unit of silicic igneous rocks occurs at the top of the lower Basalt Member

(Fig. 2). Sample Ru5910 (69²3.298 N, 30²6.389 E) was collected in situ one metre above the base of a c. 5-m-thick felsic lava flow; this flow has sharp upper and lower contacts with the encasing mafic lavas (Fig. 4d and 5) and defines a distinct marker horizon visible across the outcrop belt. Flattened vesicles are common and quartz and feldspar phenocrysts are visible in hand specimen. In thin section a fine-grained porphyritic texture is evident with phenocrysts of quartz and feldspar in a fine-grained groundmass of quartz, feldspar and opaques. This unit is a felsic (rhyolitoid) lava flow. phenocrysts of broken quartz and feldspar crystals in a fine-grained groundmass of quartz, feldspar and clays (fig. 4f). Granitoid lithics are abundant and readily visible in hand specimen and thin section (Fig. 4g). These lithics are so numerous in the tuffs that they cannot be separated from the juvenile material using conventional heavy mineral preparation techniques. In contrast, granitoid lithics in the lava flow (sample Ru5910) are rare and separation of juvenile material is possible.

\subsubsection{South Pechenga Group}

Sample Ru6510 was collected from the Porojarvi Volcanic Formation, close to the thrust separating the North and South Pechenga Groups (69¹9.396 N, 2949.102; Fig. 2). In outcrop this leucocratic rock appears to be a lava flow. In thin section, $0.4 \mathrm{~mm}$ thick leucocratic (predominantly feldspar and quartz) and melanocratic (biotite + rare amphibole) segregation bands can be observed and contain idioblastic to sub-idioblastic poikoblasts of feldspar $(0.2-0.8 \mathrm{~mm})$ orientated oblique to the banding. We interpret this quartzofeldspathic biotite ortho-schist as having a rhyolitic lava protolith. 
209 Sample Ru1 104 was collected $\left(62^{\circ} 27.421 N, 33^{\circ} 40.151 E\right)$ along the Suna River near the village of

210 Girvas, within $50 \mathrm{~m}$ of the specimen dated by Puchtel et al. (1998) at $1976 \pm 9$ Ma. The outcrop is an

211 intermediate composition lava flow with a fine-grained porphyritic texture and is as much as $27 \mathrm{~m}$

212 thick (Puchtel et al., 1998); the upper c. $5 \mathrm{~m}$ consist of columnar jointing (Fig. 4h), The lava is

213 overlain sharply by the basal unit of the Medvezhegorsk Formation, a c. $5 \mathrm{~m}$ thick, cross-bedded and

214 rippled, quartzitic and hematitic sandstone: in thin section no alteration of the sandstone is indicated

215 near the contact. The sandstones are overlain by pillowed and pahohoe lavas capped by well-

216 developed columnar jointing (Fig. 4i).

217 5.2.1 Zaonega Formation

218 Sample Ru1112 was collected on the Kuchkoma River (62 $\left.42.247 \mathrm{~N}, 35^{\circ} 46.982 \mathrm{E}\right), 200 \mathrm{~m}$ from the

219 junction with the larger Pazha River. The section contains at least six intermediate tuff layers that

220 have sharp upper and lower contacts and are laterally continuous along the length of the exposure

221 (several tens of m). Sample Ru112 consisted of $3 \mathrm{~kg}$ of the lowermost tuff ( $22 \mathrm{~cm}$-thick), which in

222 outcrop was estimated to contain as much as $25 \%$ quartz crystals in a mesocratic groundmass. Sample

223 Ru1108 was collected on the Pazha River $\left(62^{\circ} 43.641\right.$ N, 3548.436E) from a 2 m-thick gabbro that

224 has a coarse $(1 \mathrm{~cm})$ equigranular texture of feldspar and pyroxene and cross-cuts the Zaonega

225 Formation rocks.

\subsubsection{Kondopoga Formation}

227 Sample Ru1106 is from a fine- to medium-grained sandstone in the Kondopoga Quarry $\left(62^{\circ} 13.161 \mathrm{~N}\right.$, $\left.34^{\circ} 18.723 \mathrm{E}\right)$. The sandstone exhibits a slight fining-upward grading and occurs several tens of metres below a distinctive interval containing pyrobitumen intraclasts referred to as 'shungite pancakes'. 
233 Sample Ru6610 yielded two concordant Palaeoproterozoic zircon grains (z1-2) analysed by ID-TIMS

234 (Fig. 2 \& 6). Grain $\mathrm{z} 2$ is statistically concordant, but plots slightly down concordia with respect to

235 grain z1, probably representing minor Pb loss. Grain z1 was split into two fractions and analysed

236 separately $(\mathrm{z} 1 \mathrm{a}, \mathrm{b})$; both fractions are concordant. The ${ }^{207} \mathrm{~Pb} /{ }^{206} \mathrm{~Pb}$ dates $(\mathrm{n}=3)$ overlap, within error,

237 and yield an age at $1922.6 \pm 1.1 \mathrm{Ma}$. This is a minimum age for the stratigraphic level from which

238 Ru6610 was collected; however, given the similarity of this age to other ages reported in this study it

239 may be inferred that $1922.6 \pm 1.1 \mathrm{Ma}$ also represents the crystallisation age of the gabbro intrusion,

240 and the age of volcanism at this stratigraphic level.

\subsubsection{Pilgujärvi Sedimentary Formation}

243

Zircon grains from sample Ru5410 were analysed by the LA-ICPMS method. Concordant $( \pm 5 \%)$ ${ }^{207} \mathrm{~Pb} /{ }^{206} \mathrm{~Pb}$ ages were between c. $2977 \mathrm{Ma}$ and $1917 \mathrm{Ma}(\mathrm{n}=89)$, with the majority between c. 2095 Ma and $2010 \mathrm{Ma}(\mathrm{n}=66)$. The youngest two concordant ${ }^{207} \mathrm{~Pb} /{ }^{206} \mathrm{~Pb}$ ages are from $\mathrm{z} 44,1917 \pm 5 \mathrm{Ma}$, and z67, $1969 \pm 4$ Ma. The two youngest single zircon crystals (z44, z 67) were subsequently analysed by ID-TIMS (Fig. 6), yielding concordant ${ }^{207} \mathrm{~Pb} /{ }^{206} \mathrm{~Pb}$ ages at $1922.8 \pm 1.6 \mathrm{Ma}(\mathrm{z} 44)$ and $1943.9 \pm 2.9(\mathrm{z} 67)$. The $1922.8 \pm 1.6 \mathrm{Ma}$ age is taken as the preferred, minimum age of the stratigraphic level where sample Ru5410 was collected.

\subsubsection{Pilgujärvi Volcanic Formation}

\subsubsection{Mafic Tuff}

From sample Ru5610 a fraction of one zircon (z1b) and three zircon grains (z8, z9, z11) were analysed by ID-TIMS and yield concordant results (Fig. 6). The ages of the four grains are equivalent, within error, but $\mathrm{zlb}$ yields a distinctly older ${ }^{207} \mathrm{~Pb} /{ }^{206} \mathrm{~Pb}$ date suggesting possible inheritance. The weighted average ${ }^{207} \mathrm{~Pb} /{ }^{206} \mathrm{~Pb}$ age of $\mathrm{z} 8, \mathrm{z} 9$ and $\mathrm{z} 11$ is $1919.2 \pm 1.3 \mathrm{Ma}(\mathrm{n}=3)$, which we interpret as the eruption age of this tuff and the depositional age of this stratigraphic level.

\subsubsection{Felsic Lava Flow}


259 Thirteen of the 18 grains analysed by LA-ICPMS from sample Ru5910 have ${ }^{207} \mathrm{~Pb} /{ }^{206} \mathrm{~Pb}$ dates

260 between 1919 and 1888 Ma (Fig. 5b); eleven of those were subsequently analysed by ID-TIMS (Fig.

$2615 \mathrm{c}, 6)$. Grain $\mathrm{z} 3$ yielded a weakly discordant $\mathrm{Archaean}{ }^{207} \mathrm{~Pb} /{ }^{206} \mathrm{~Pb}$ age at $2727.8 \pm 2 \mathrm{Ma}$. Grain z8

262 yields a concordant ${ }^{207} \mathrm{~Pb} /{ }^{206} \mathrm{~Pb}$ date at $2057.64 \pm 2.28 \mathrm{Ma}$, which is, within error, equivalent to the

263 Kolosjoki Sedimentary Formation volcanism (Martin et al., 2013b). Grain z15 yields a concordant

$264{ }^{207} \mathrm{~Pb} /{ }^{206} \mathrm{~Pb}$ date at $1986.80 \pm 1.76 \mathrm{Ma}$ that is equivalent to the single, previously reported ${ }^{207} \mathrm{~Pb} /{ }^{206} \mathrm{~Pb}$

265 date at $1988 \pm 3 \mathrm{Ma}$ (Hanski et al., 2014) and is interpreted here as a xenocrystic grain. Grains z6

266 yields a concordant ${ }^{207} \mathrm{~Pb} /{ }^{206} \mathrm{~Pb}$ date at $1924.15 \pm 1.5 \mathrm{Ma}$ that is equivalent to ages reported here from

267 the Pilgujärvi Sedimentary and Kolosjoki formations and is considered to be inherited from these or

268 similar-aged rocks. Grains z10, z15 and z22 are discordant, perhaps reflecting incomplete removal of

269 metamict zones during the chemical abrasion process. Grains z2, z5 and z14 overlap within

270 uncertainty and yield a concordant ${ }^{207} \mathrm{~Pb} /{ }^{206} \mathrm{~Pb}$ date at $1897.9 \pm 1.3 \mathrm{Ma}$ (Fig. 6) that is interpreted as

271 the crystallisation age. Grain z22 yields a concordant ${ }^{207} \mathrm{~Pb} /{ }^{206} \mathrm{~Pb}$ date at $1903.0 \pm 1.48 \mathrm{Ma}$ that plots

272 slightly up concordia from the inferred crystallisation age suggesting it may have experienced slight

273 open-system behaviour.

\subsubsection{Felsic Tuff}

276

277

278

Four separate felsic tuffs were sampled in the field that both stratigraphically underlie (Ru6210, Ru5710) and overlie (Ru6010, Ru6110) the dated felsic lava flow (sample Ru5910 and Fig. 5a). Zircon grains from samples Ru6210, Ru5710 and Ru6110 were analysed by LA-ICPMS analysis prior to ID-TIMS analysis, with results given in Table S2 and concordia plots (2100-1850 Ma) in Fig. 5b-c. Sample Ru6010 yielded very few zircons and these were analysed only by the ID-TIMS method.

Twenty-five zircon grains were analysed by LA-ICPMS from the stratigraphically lowest sample, Ru6210, at the base of the felsic interval; these yielded a spread of ages between c. 2100 and $1900 \mathrm{Ma}$ (Fig. 5b) and a second population between 3000 and 2700 Ma. Six single zircon grains (z4, $\mathrm{z6}, \mathrm{z16}, \mathrm{z17}, \mathrm{z} 21, \mathrm{z} 26)$ from that sample were analysed by ID-TIMS. Grain z16 yields a ${ }^{207} \mathrm{~Pb} /{ }^{206} \mathrm{~Pb}$ 
age at c. 2737 Ma that is interpreted as a xenocrystic grain, most likely from assimilation of the Archaean basement. Grain $\mathrm{z} 4$ is discordant with a ${ }^{207} \mathrm{~Pb} /{ }^{206} \mathrm{~Pb}$ age at c. 2091 ; this grain has likely experienced open system behaviour. The other four grains (z6, 17, 21, 26) are concordant and overlap, within error, yielding a ${ }^{207} \mathrm{~Pb} /{ }^{206} \mathrm{~Pb}$ age at c. $1989 \mathrm{Ma}$. In sample Ru5710, 104 zircon grains were analysed by LA-ICPMS and plot in two populations at c. $2700 \mathrm{Ma}$ and between c. 2050 and $1950 \mathrm{Ma}$ (Fig. 5b). Six single zircon grains were taken and analysed by ID-TIMS from the younger population (z11, z18, z40, z47, z50, z51) and yield concordant ages that overlap, within error, and have a ${ }^{207} \mathrm{~Pb} /{ }^{206} \mathrm{~Pb}$ age at c. $1986 \mathrm{Ma}$ (Fig. 5). Six single zircon grains (z1-5, z10) were analysed from sample Ru6010 by ID-TIMS. Grain z5 is very weakly discordant and yields a ${ }^{207} \mathrm{~Pb} /{ }^{206} \mathrm{~Pb}$ age at c. $1990 \mathrm{Ma}$. Grain $\mathrm{z} 3$ is discordant and yields a ${ }^{207} \mathrm{~Pb} /{ }^{206} \mathrm{~Pb}$ age at c. $2002 \mathrm{Ma}$; this grain is interpreted to have experienced open system behaviour and as such its age is considered unreliable. Grain z10 displays an equal degree of discordance as z3 and yields a ${ }^{207} \mathrm{~Pb} /{ }^{206} \mathrm{~Pb}$ age at c. $1987 \mathrm{Ma}(\mathrm{Th} / \mathrm{U}=0.5$; Fig. S2). Grains z1-2 and z4 are concordant and overlap, within error, yielding a ${ }^{207} \mathrm{~Pb} /{ }^{206} \mathrm{~Pb}$ age at c. $1988 \mathrm{Ma}$ (Fig. 5c). Seventeen zircon grains were analysed by LA-ICPMS from sample Ru6110 and plot as two populations between c. 2950 and $2750 \mathrm{Ma}$ and between 2090 and $1900 \mathrm{Ma}$ (Fig. 5b). Three single zircons (z2-3, z5) and two zircon fractions from a single grain (z1a, b) were subsequently analysed by ID-TIMS. Grain z2 is very weakly discordant, suggesting a minor amount of $\mathrm{Pb}$-loss, and yields a ${ }^{207} \mathrm{~Pb} /{ }^{206} \mathrm{~Pb}$ age at c. $1988 \mathrm{Ma}$. Zircon fraction z1b plots slightly down concordia from z1a, z3, z5, but has a comparable ${ }^{207} \mathrm{~Pb} /{ }^{206} \mathrm{~Pb}$ age at c. $1988 \mathrm{Ma}$, suggesting minor $\mathrm{Pb}$ loss. The remaining three fractions (z1a, z3, z5) overlap, within uncertainty, and yield a ${ }^{207} \mathrm{~Pb} /{ }^{206} \mathrm{~Pb}$ age at c. $1987 \mathrm{Ma}$ (Fig. 5c).

In summary, zircon grains from felsic igneous units in the Pilgujärvi Volcanic Formation analysed by the LA-ICPMS method show a range of ages between 2000 and 1900 Ma in samples Ru6210, Ru5910 and Ru6110 and between 2050 and 1950 Ma in sample Ru5710. All samples also have a population of Archaean zircons. Subsequent analysis of zircon grains (sample Ru5910) by IDTIMS yielded an $1897.9 \pm 1.3 \mathrm{Ma}$ age for the felsic lava flow, and c. 1980 Ma dates for the felsic tuffs (Fig. 5). We interpret the $1897.9 \pm 1.3 \mathrm{Ma}$ as the eruption age of the lava flow, which is supported by the youngest LA-ICPMS dates on individual zircon grains in samples Ru6210 and Ru6110. 
Eight zircon grains (z1, z3-7, z9-10) were analysed by the ID-TIMS method from sample Ru6510. All eight grains form a chord, with grains z1, z3 and z6-7 being weakly discordant and anchored to concordia by grains z5, z9-10. Grain z4 has significant errors in comparison to the other grains analysed, perhaps suggesting the presence of micro-inclusions. The upper intercept age of all eight grains is $1936.5 \pm 1.3 \mathrm{Ma}$ (lower intercept c. $471 \mathrm{Ma}$ ) and is taken as a crystallisation age for this unit.

\section{4 $\mathrm{U}$-Pb results from Onega Basin}

321

322

\subsubsection{Jangozero Formation}

Sample Ru1104 yielded zircon and baddeleyite grains. The seven baddeleyite grains and zircon grains $\mathrm{z} 5$ and $\mathrm{z} 9$ yield an upper intercept age at $1975.3 \pm 2.8 \mathrm{Ma}(\mathrm{MSWD}=1.13, \mathrm{n}=10$; Fig. 6$)$ that is interpreted as the crystallisation age of the lava flow. Note that the baddeleyite discordance is the result of $\mathrm{Pb}$-loss, the lower intercept indicating disturbance at $312 \pm 82 \mathrm{Ma}$.

\subsubsection{Zaonega Formation}

Sample Ru1112 yielded 40 zircon grains that were first analysed by LA-ICPMS. Thirty-five zircon grains, both concordant and forming a chord pointing towards zero age lead loss, yielded Archaean ${ }^{207} \mathrm{~Pb} /{ }^{206} \mathrm{~Pb}$ ages. Four zircons yielded discordant Palaeoproterozoic ages and grain z39 yielded a concordant ${ }^{207} \mathrm{~Pb} /{ }^{206} \mathrm{~Pb}$ age at $1978 \pm 13 \mathrm{Ma}$. Grain z39 was subsequently analysed by ID-TIMS and yielded a weakly discordant datum that, assuming zero age Pb-loss, yields an upper intercept age at $1982.0 \pm 4.5$ (Fig. 6), which is within error of the LA-ICPMS datum. This is assumed to be a maximum age for eruption of the felsic tuff. Sample Ru1108 yielded eight zircon grains that were analysed by LA-ICPMS; these gave Archaean ages and one Palaeoproterozoic age (z2). Zircon 2 was then analysed by ID-TIMS and yielded a concordant ${ }^{207} \mathrm{~Pb} /{ }^{206} \mathrm{~Pb}$ age at $1961.6 \pm 5.1 \mathrm{Ma}$ (Fig. 6). 
Sample Ru1 106 yielded 15 zircon grains that were first analysed by LA-ICPMS. Two grains (z2 and z7) yield inherited Archaean ${ }^{207} \mathrm{~Pb} /{ }^{206} \mathrm{~Pb}$ ages, four grains (z1, z3, z5 and $\mathrm{z6}$ ) yield ${ }^{207} \mathrm{~Pb} /{ }^{206} \mathrm{~Pb}$ ages between 2051 and $2001 \mathrm{Ma}$, and the remaining nine zircon grain ages overlap, within uncertainty, yielding a weighted average ${ }^{207} \mathrm{~Pb} /{ }^{206} \mathrm{~Pb}$ age at $1974.6 \pm 7.6 \mathrm{Ma}(\mathrm{MSWD}=2)$. Subsequently, grains z1, z4, z12 and z13 were analysed by ID-TIMS and grains z1 and z12 overlap within error and yield a concordant ${ }^{207} \mathrm{~Pb} /{ }^{206} \mathrm{~Pb}$ age at $1967.6 \pm 3.5 \mathrm{Ma}(\mathrm{MSWD}=0.75$; Fig. 6); this is interpreted as the maximum depositional age. Zircon z13 has had minor Pb-loss and z4 is weakly reversely discordant.

\section{Discussion}

\subsection{Geochronology}

\subsubsection{Pechenga}

The new data derived in this study constrain deposition of the Pilgujärvi Sedimentary Formation to between $1922.8 \pm 1.6$ and $1919.2 \pm 1.3 \mathrm{Ma}$, and the sampled section of the Pilgujärvi Volcanic Formation to between 1919.2 \pm 1.3 and $1897.9 \pm 1.3$ Ma. These ages are c. 60 Myr younger than the recently reported c. 1990 Ma age for those rocks (Hanski et al., 2014), but are relatively closer in age to the lower error limits of single isochron methods (e.g. a Sm-Nd age at $1990 \pm 66 \mathrm{Ma}$ and a Re-Os age at $1980 \mathrm{Ma}$ with estimated errors at $\pm 40 \mathrm{Ma}$ ). Wall rock contamination is a known issue for igneous rocks from Pechenga, as noted by this study (Fig. 4g), Walker et al. (1997), Skuf'in and Bayanova (2006) and Hanski et al. (2014), and underscored by the presence of numerous granitoid lithics in the felsic tuffs. That, combined with the small number of non-inherited zircon grains (compared to those that are inherited) typically recovered from these rocks, is a likely reason why previous age determinations are too old (c. 1990 Ma). The c. 1980 Ma ages (Skuf'in and Bayanova, 2006) for gabbro-wehrlite intrusions into the Pilgujärvi sedimentary units are in conflict with our 
362

363

geochronology and we have no clear-cut explanation for this discrepancy. However, we have confidence in our age determinations for the following reasons: 1) the new ages obey stratigraphic order - our zircon dates at the top of the section are younger than those at the base; 2) the ages are not significantly different from the lower estimates of existing single isochron methods; and 3) the textural characteristics of the analysed zircons combined with their $\mathrm{Th} / \mathrm{U}$ ratios being $>0.2$ are consistent with an igneous origin and not with a metamorphic one (Fig. S2). The new dating also provides the first direct age constraint for the South Pechenga Group at $1936.5 \pm 1.3$ Ma. The Pechenga geochronology implies that an unconformity is present within the Kolosjoki Sedimentary Formation between the rocks yielding the 2056.6 \pm 0.8 Ma age of Martin et al. (2013b) and those yielding the $1916 \pm 1$ Ma maximum depositional age of Gärtner et al. (2011) (Fig. 2). Lastly, the Luchlompolo Thrust explains the out-of-sequence chronology between the $1916 \pm 1$ Ma age (Gärtner et al., 2011) and the 1922.6 \pm 1.1 Ma age (Ru5610) of this study for the lower part of the overlying Kolosjoki Volcanic Formation (Fig. 2).

\subsubsection{Onega Basin}

A clearly exposed outcrop of the Jangozero Formation was targeted for geochronology. The sharp, laterally continuous lower contact, upwards facing columnar jointing and fine-grained porphyritic texture of the outcrop are evidence that the sample was taken from a lava flow and not a cross-cutting intrusion. The age of this rock, $1975.3 \pm 2.8$, overlaps with a previously determined age of $1976 \pm 9$ Ma made by Puchtel et al. (1998) on this igneous body. The Kondopoga Formation in the upper part of the Onega succession is here constrained from detrital zircons to a maximum age of $1967.6 \pm 3.5$ Ma. This overlaps with the $1969 \pm 18$ Ma Re-Os age determined by Puchtel et al. (1999) on the stratigraphically underlying Suisari Formation. Thus, our new geochronology indicates that the deposition of the Onega Basin succession is constrained to between 1975.3 \pm 2.8 and $1967.6 \pm 3.5$ Ma, which concurs with that determined by Puchtel et al. (1999; 1998). Our ID-TIMS U-Pb dating of single zircon grains from tuffs and a sill in the Zaonega Formation (Ru112; Ru1108) support this suggested age range for the Onega Basin succession. 
391 Our data for the CBE- and Lomagundi-Jatuli Event-bearing units yield three key results. Firstly, the age of the Pilgujärvi CBE and Ni-mineralised Productive Formation must be younger than the 1922.8 $\pm 1.6 \mathrm{Ma}$ age of the youngest detrital zircon obtained from the Pilgujärvi sedimentary rocks (Ru5410) but older than the 1919.2 \pm 1.3 Ma age of the mafic tuff in the basal part of the overlying Pilgujärvi Volcanic Formation (Ru5610). Secondly, the Zaonega CBE, which defines the type area of the Shunga Event, is bracketed between a maximum age of $1975.3 \pm 2.8 \mathrm{Ma}$ (the lava in the underlying Jangozero Formation; Ru1104) and a minimum age of $1967.6 \pm 3.5 \mathrm{Ma}$ (the youngest detrital zircon in the overlying Kondopoga Formation; Ru1106), indicating that the Zaonega CBE is c. 1970 Ma thus much older than the c. 1920 Ma Pilgujärvi CBE. Thirdly, our new age constraints restrict the depositional duration of the ${ }^{13} \mathrm{C}$-rich $(>+5 \%$ ) carbonate rocks of the Tulomozero and Zaonega formations to the same time window (c. $1970 \mathrm{Ma}$ ) and thereby make those rocks younger than the previously known age brackets on the timing of the Lomagundi-Jatuli Event based on successions elsewhere (c. 2300-2060 Ma), including the Pechenga Greenstone Belt (e.g. Martin et al., 2013a).

\subsection{Timing of Carbon Burial Events (CBEs)}

406

407
Two other CBE-bearing Palaeoproterozoic units have figured prominently in ideas about Earth System operation in the aftermath of the GOE; the Francevillian Basin in Gabon (Canfield et al., 2013; Préat et al., 2011; Weber and Gauthier-Lafaye, 2013) and the Whites and Koolpin formations of the Pine Creek Orogen in northern Australia (Worden et al., 2008). The radiometric constraints to deposition of the Francevillian Basin sediments are restricted by a U-Pb zircon date from FD Formation volcanism at $2083 \pm 6$ Ma (TIMS; Horie et al. 2005) and several other radiometric techniques produce dates at or around this age with variable uncertainty (see Martin et al. 2013 and Préat et al., 2011 for a summary of the age constraints). The Horie et al. (2005) data are generally accepted in other studies as contemporaneous with sedimentation (e.g. Préat et al., 
2011) and are used here. Thus age constraints (Fig. 7, 8) place the timing of deposition of the organic-rich Francevillian FD Formation at $2083 \pm 6 \mathrm{Ma}$ (Horie et al., 2005) and bracket that of the Whites Formation to between $2021 \pm 10$ Ma and $2019 \pm 4$ Ma, and the Koolpin Formation to likely be not much older than $1863 \pm 2 \mathrm{Ma}$, the age of the overlying Gerowie Tuff (age data from Needham et al., 1988, and Worden et al., 2008). Those age constraints, when combined with our interpretations of the new data from northwest Russia, show that each of the main Palaeoproterozoic CBEs, the Pilgujärvi Sedimentary, Zaonega, Francevillian FD, Whites and Koolpin formations, are temporally discrete episodes punctuating the c. 2.1-1.85 Ga interval, with a quasi-periodic recurrence of c. $50 \mathrm{Ma}$ (c. 2080, 2020, 1970, 1920 and 1860 Ma; Fig. 7, 8). If the age of any one of the CBE-bearing formations is changed by improved chronology, the story for repeated events remains valid. Durations are not well constrained but the data imply c. $10^{6}$ year extents. Thus, pace Kump et al. (2011), it now appears less likely that the Francevillian and Shunga events were contemporaneous, thereby casting doubt on the concept of a singular, synchronous global-scale genetic mechanism, and obliging the investigation of alternative ideas to explain CBEs.

\subsection{A link between Carbon Burial Events and Large Igneous Provinces}

The Mesozoic is another time in Earth history when repetitive episodes of enriched organic carbon burial events occurred, the Mesozoic Oceanic Anoxic Events (OAEs). As discussed in more detail below, OAEs are superficially similar to CBEs, and both can be linked to the eruption of Large Igneous Provinces (LIPs; e.g. Adams et al., 2010; Hermoso et al., 2012; Tejada et al., 2009), which invites the question whether LIPs may also influence CBEs.

The term LIP, introduced by Coffin and Eldholm (1992), is an umbrella term to include continental flood basalt provinces, oceanic plateaus, volcanic rifted margins and aseismic ridges. Using the internationally recognised LIP database (http://www.largeigneousprovinces.org/) (following Ernst and Buchan, 2001) the median age of each LIP event between 2.1 and 1.8 Ga was placed into 10-Myrduration age bins and plotted against volume $\left(\mathrm{km}^{3}\right)$. The result (Fig. 7, Table S5) shows that several 
441 LIP events temporally coincide with the CBEs: Unit FD (Gabon) is preceded by the Snowy Pass and

442 Cauchon Event; the Whites Formation is preceded by LIP eruptions in Canada and Greenland and 443 overlaps with the Slave province Lac de Gras Event; the Zaonega Formation is preceded by the Indian 444 Agali-Anaikatti Event and overlaps with the $600000 \mathrm{~km}^{3}$ Northern Baltica-2 Event; the Pilgujärvi 445 Sedimentary Formation overlaps with the Canadian Chukotat Event; and the Koolpin Formation overlaps with the Australian Biscay Event and Canadian events. The general coincidence in timing between Proterozoic LIPs and CBEs, be they Mesozoic or Palaeoproterozoic in age, suggests that, akin to Mesozoic OAEs, large-scale volcanism aids in generating the circumstances that can lead to enhanced accumulation of organic-rich sediments (e.g. Adams et al., 2010; Tejada et al., 2009).

\subsection{Are Palaeoproterozoic CBEs Deep-Time analogues of Mesozoic OAEs?}

Palaeoproterozoic CBEs and Mesozoic OAEs share several similarities: both are intervals of enriched organic matter content relative to encasing strata, both have temporal association to the eruption of LIPs, and both are proposed to be a result of feedback mechanisms operating between nutrient supply and primary productivity during times of enhanced chemical weathering in association with marine euxinic and even anoxic conditions (e.g. Canfield et al., 2013; Hermoso et al., 2012; Jenkyns, 1988; Kump et al., 2011). CBEs and OAEs do differ in terms of thickness (100s of meters versus many meters) and duration (c. $10^{6}$ years versus c. $10^{5}$ years), which should excite research efforts for modelling cause-and-effect feedbacks. A feature of Palaeoproterozoic CBEs that has been highlighted by several workers, regardless of their often contrasting interpretations of the phenomena, is a comparable stepped pattern towards lower $\delta^{13} \mathrm{C}_{\text {organic }}$ values going into a CBE followed by a stabilisation, or even recovery towards isotopically heavier values, exiting one (Kump et al., 2011; Weber and Gauthier-Lafaye, 2013); intriguingly, a not dissimilar pattern (Fig. 9; Table S6) also typifies some Mesozoic OAEs (e.g. Hermoso et al., 2012). Even though Kump et al. (2011) assumed that the Shunga and Francevillian events were broadly coincident, their explanation for excursion to low $\delta{ }^{13} \mathrm{C}$ organic matter during a Palaeoproterozoic CBE nevertheless remains viable: oxidative weathering of widespread organic matter sequestered during a prior high $\delta^{13} \mathrm{C}_{\text {carbonate }}$ event, leading to 
468 low $\delta{ }^{13} \mathrm{C}$ atmosphere and ocean. A corollary requires that open-marine coupled organic matter-

469 carbonate carbon primary $\delta{ }^{13} \mathrm{C}$ isotope records should be positively correlated and data from the

470 Zaonega Formation (Kump et al., 2011) based on the upper part (above $250 \mathrm{~m}$ depth) of drill core for

471 FAR-DEEP Hole $12 \mathrm{AB}$ hint at this possibility. An alternative model favoured by some workers is that

472 contemporaneous magmatic activity helped drive biological productivity, similar to modern-day

473 settings, and that the conditions for generating the isotopic and organic-accumulation patterns of

474 CBEs can be explained by basin-specific processes involving methane; these do not require

475 mechanisms operating on a worldwide scale (e.g. Lepland et al., 2014; Qu et al., 2012). Determining

476 which of these scenarios is more apropos to the genesis of Palaeoproterozoic CBEs offers a rich area

477 for research and warrants more thorough and detailed investigation of each CBE. Črne et al. (2014)

478 provide a starting point for the Onega Basin, as shown by their detailed carbonate rock study

479 discriminating primary and secondary isotopic signatures as a test of whether the isotopic variations

480 are likely local, regional or global in origin.

481

482

\subsection{Timing of Ni-mineralisation}

483

484

485

486

487

488

489

490

491

492

The Pilgujärvi Sedimentary Formation (Productive Formation) in the North Pechenga succession hosts one of the world's richest $\mathrm{Ni}$ deposits. The age of Ni mineralisation has been generally thought to be c. $1990 \mathrm{Ma}$, separating it from a global pulse of Ni mineralisation at around $1900 \mathrm{Ma}$ (Hoatson et al., 2006). Our new ages now show that the age of the Pilgujärvi (Productive) Sedimentary Formation is between $1922.8 \pm 1.6 \mathrm{Ma}$ and $1919.2 \pm 1.3 \mathrm{Ma}$. This overlaps with the recognised global pulse of Ni mineralisation (Hoatson et al., 2006) (Fig. 7; Table S7), reinforcing the concept that this was a period of significant worldwide mineralisation. The timing of Pechenga Ni mineralisation also overlaps with a pulse of volcanic massive sulphide (VMS) deposition (Bekker et al., 2010) and coincides with the global return of iron formations (Isley and Abbott, 1999). The linkage between these various phenomena is intriguing and remains to be determined. 


\section{Summary and conclusions}

495

496

497

498

499

500

501

502

503

504

505

506

507

508

509

510

511

512

513

514

515

516

517

518

New high precision U-Pb (zircon and baddeleyite) ID-TIMS data reveal that in NW Russia there are two distinct periods of accumulation of Palaeoproterozoic organic-rich sedimentary rocks (termed by us carbon burial episodes or CBEs) and rocks recording the Lomagundi-Jatuli Event. Given our inferences regarding geological relationships, the Pilgujärvi Sedimentary Formation CBE in the Pechenga Greenstone Belt on the Kola craton (and inferentially the Ni-mineralised Productive Formation) was deposited between $1922.8 \pm 1.6$ and 1919.2 \pm 1.3 Ma whereas the Zaonega Formation in the Onega Basin on the Karelia craton was deposited between 1975.3 \pm 2.8 and 1967.6 \pm 3.5 Ma. By comparison with sections in northern Australia and Gabon it can be shown that CBEs on four disparate cratons were temporally discrete depositional episodes occurring between c. 2.1 and 1.85 Ga. Furthermore we can show that the Lomagundi-Jatuli Event terminated in the Pechenga Greenstone Belt by c. 2060 Ma (Martin et al., 2013b) but deposition of the Zaonega and Tulomozero formations that record values of carbonate $\delta^{13} \mathrm{C}$ up to $17.2 \%$ was ongoing at c. $1970 \mathrm{Ma}$. This is inconsistent with models that treat these isotopic phenomena as representing a single, global event.

A close association between large-scale volcanism and organic matter accumulation combined with a distinctive trend of $\delta^{13} \mathrm{C}_{\text {organic }}$ for Palaeoproterozoic CBEs is reminiscent of Mesozoic OAEs and may suggest a commonality of causes. Determining whether individual Palaeoproterozoic CBEs were global or regional requires additional geochronology, but given existing constraints the conditions for generating the isotopic and organic-accumulation patterns of CBEs can be explained by either global-scale (e.g. Kump et al., 2011) or basin-specific processes (e.g. Lepland et al., 2014; Qu et al., 2012). Our findings show that hallmark events of the Palaeoproterozoic Earth in the aftermath of the Great Oxidation Event have features not dramatically unlike some known for the Phanerozoic Earth. Perhaps the corollary is that once the transformation of Earth from an anoxic to oxic planet occurred, biogeochemical processes began operating that, as in the case of organic-rich rocks, do not necessitate searching for processes requiring explanations unique to the Precambrian. 


\section{Acknowledgements}

521 APM, DJC, ARP and AEF were supported by NERC grant NE/G00398X/1. All geochronology was 522 undertaken at NERC Isotope Geosciences Laboratory, Keyworth, United Kingdom. Fieldwork was

523 supported by a Royal Society International Travel Grant. We thank L. Kump and anonymous

524 reviewers for their helpful comments and M. Bickle for editorial handling. 
525 Figure 1 The location of the Pechenga Greenstone Belt and the Onega Basin, Russia

526 Figure 2 Stratigraphic section from Pechenga; data from additional publications have been included

527

528

529

530

531

532

533

534

535

536

537

538

539

540

541

542

543

544

545

546

547

548

549

550

where relevant. Radiometric ages from this study are shown in red text. The carbonate $\delta^{13} \mathrm{C}$ values (in green) are from Melezhik et al. (2007). Dashed line adjacent to the Kolosjoki Sedimentary Formation marks the approximate position of an intra-formational unconformity. Luch: Luchlompolo Thrust.

Dark-blue bars denote the stratigraphic position of FAR-DEEP drill holes.

Figure 3 Onega Basin stratigraphic section; data from additional publications have been included where relevant. The carbonate $\delta^{13} \mathrm{C}$ values (in green) are from Melezhik et al. (1999) for the Tulomozero Formation and from Kump et al. (2011) for the Zaonega Formation. Dark-blue bars denote the stratigraphic position of FAR-DEEP drill holes. Dashed line denotes an unconformity.

Figure 4 Outcrop and thin section images of the dated samples. a. Sandstone outcrop of the Pilgujärvi Sedimentary Formation from which Ru5410 was sampled. b. Thin tuff in outcrop (white arrow) from the base of the Pilgujärvi Volcanic Formation (Ru5610). c. Thin section photograph in plane-polarised light of Pilgujärvi mafic tuff showing angular crystal fragments and scoria (S) clast typical of a primary volcaniclastic rock. d. Felsic, rhyolitoid lava flow (Ru5910) in the middle part of the Pilgujärvi Volcanic Formation. e. Felsic tuff in outcrop showing the top of a coarser, crystal-rich tuff (Ru5710) overlain by a finer-grained, layered tuff. f. Thin-section photograph in cross-polarised light of a rhyolitoid tuff (Ru6010; representative of the textures seen in all the rhyolitoid tuffs described in the text) with fragments of volcanic quartz (Qtz) and ragged pumice (P) clasts hosted in a fine-grained groundmass of quartz, feldspar, pumice and altered glass. g. A granitoid lithic fragment with quartz (Qtz) and feldspar (Fsp) in a tuff (Ru6010); such clasts are common in the samples yielding the c. 1988 Ma xenocrystic grains. h. Plan view showing hexagonal columnar jointing at the top of the Jangozero lava flow of sample Ru1104. i. Columnar joints in a lava flow above the sampled unit shown in (h). 
552 Figure 5 Simplified vertical stratigraphy of the felsic interval in the Pilgujärvi Volcanic Formation (a) 553 and conventional concordia plots for samples analysed by the LA-ICPMS (b) and ID-TIMS methods

554 (c). Note that difference in scales between concordia in panels $\mathbf{b}$ and $\mathbf{c}$, and the breaks in scale in 555 panel a within the mafic lava flow intervals.

556

557 Figure 6 Conventional concordia plot for zircons from samples from Pechenga (Ru6510, Ru5910, 558 Ru5610, Ru5410, Ru6610) and Onega Basin (Ru1106, Ru1108, Ru1112, Ru1104) for single zircon 559 (z) and baddeleyite (b) grains and fractions analysed by the ID-TIMS method. The plots are presented 560 in stratigraphic order with Pechenga on the left and Onega Basin on the right.

561

Figure 7 Summary of the age distributions of selected Palaeoproterozoic events and carbon burial events (dark grey bars): Large Igneous Provinces (LIPs) in 10-Myr bins (Ernst and Buchan, 2001); total organic carbon (TOC; Canfield et al., 2013; Melezhik et al., 2013); volcanogenic massive sulphide (VMS) and nickel data (Bekker et al., 2010; Hoatson et al., 2006); iron formation (BIF; Isley and Abbott, 1999). Pilgujärvi Sedimentary and Zaonega formations are from the North Pechenga Group and Onega Basin, NW Russia; Koolpin and Whites formations are in the Pine Creek Inlier, northern Australia; the Francevillian succession is in Gabon.

Figure 8 Generalised stratigraphic columns of the Franceville Basin (Gabon), Pine Creek Orogen (Australia), Onega Basin (NW Russia) and Pechenga Greenstone Belt (NW Russia) arranged according to the age constraints for their respective CBE-bearing units. Age data from this study are shown in red; other age data are: 1 (Horie et al., 2005), 2 (Gancarz, 1978), 3 (Worden et al., 2008), 4 (Puchtel et al., 1998), 5 (Gärtner et al., 2011), 6 (Martin et al., 2013b), 7 (Melezhik et al., 2007). All age errors are given at $2 \sigma$. Kon $=$ Kondopoga. Med $=$ Medvezhegorsk. Jan $=$ Jangozero. $\mathrm{PiS}=$ 
576 Pilgujarvi Sedimentary. $\mathrm{KoS}=$ Kolosjoki Sedimentary. KuS $=$ Kuetsjärvi Sedimentary. Luch. $=$

577 Luchlompolo. Carbonate carbon $\delta^{13} \mathrm{C}$ vales (in green) are: a (Krupenik et al., 2011; Kump et al., 578 2011), b (Melezhik et al., 1999), c (Melezhik et al., 2007).

579

580 Figure 9 Comparison of $\delta^{13} \mathrm{C}_{\text {organic }}$ (\%o V-PDB) profiles between the Palaeoproterozoic rocks in the

581 Francevillian Basin, Gabon (Gauthier-Lafaye and Weber, 2003; $\mathrm{n}=100$ ) and Zaonega Formation,

582 Russia (Kump et al., 2011; Lepland et al., 2014; $n=60$ ), to the Mesozoic Toarcian Oceanic Anoxic

583 Event (OAE) of the Paris Basin (Hermoso et al., 2012; $n=128)$. CBE-carbon burial episode; vertical

584 bars colour-coded to each section denote the stratigraphic positions of organic-rich rocks. Although

585 the Palaeoproterozoic successions exhibit much greater overall thicknesses (100's of metres) relative

586 to the Toarcian section (metres), each carbon-isotope profile is marked by stepped declines followed

587 by a stabilisation. Note that for the Zaonega profile some of the data at c. $30-40 \%$ of relative thickness

588 (c. $150 \mathrm{~m}$ depth in FAR-DEEP Hole 12AB; (Črne et al., 2014) are out of sequence because of

589 migrated hydrocarbons (Kump et al., 2011). The data used in compiling this plot are in Table S6 in

590 the Data Repository.

591

592

593

594

595

596

597

598

599

600

601

602 


\section{References}

605

606

607

608

609

610

611

612

613

614

615

616

617

618

619

620

621

622

623

624

625

626

627

628

629

630

631

632

633

634

635

636

637

638

639

640

641

642

643

644

645

646

647

648

649

650

651

Adams, D.D., Hurtgen, M.T., Sageman, B.B., 2010. Volcanic triggering of a biogeochemical cascade during Oceanic Anoxic Event 2. Nat Geosci 3, 201-204.

Amelin, Y.V., Heaman, L.M., Semenov, V.S., 1995. U-Pb geochronology of layered mafic intrusions in the eastern Baltic Shield: implications for the timing and duration of Paleoproterozoic continental rifting. Precambrian Res 75, 31-46.

Bekker, A., Holland, H.D., 2012. Oxygen overshoot and recovery during the early Paleoproterozoic. Earth Planet Sci Lett 317-318, 295-304.

Bekker, A., Slack, J.F., Planavsky, N., Krapež, B., Hofmann, A., Konhauser, K.O., Rouxel, O.J., 2010. Iron Formation: The Sedimentary Product of a Complex Interplay among Mantle, Tectonic, Oceanic, and Biospheric Processes. Econ Geol 105, 467-508.

Canfield, D.E., 2005. The early history of atmospheric oxygen. Annual Review of Earth and Planetary Sciences 33, 1-36.

Canfield, D.E., Ngombi-Pemba, L., Hammarlund, E.U., Bengtson, S., Chaussidon, M., Gauthier-Lafaye, F., Meunier, A., Riboulleau, A., Rollion-Bard, C., Rouxel, O., Asael, D., Pierson-Wickmann, A.C., El Albani, A., 2013. Oxygen dynamics in the aftermath of the Great Oxidation of Earth's atmosphere. Proceedings of the National Academy of Sciences 110, 16736-16741.

Coffin, M.F., Eldholm, O., 1992. Volcanism and continental break-up: a global compilation of large igneous provinces. Geological Society, London, Special Publications 68, 17-30.

Črne, A.E., Melezhik, V.A., Lepland, A., Fallick, A.E., Prave, A.R., Brasier, A.T., 2014. Petrography and geochemistry of carbonate rocks of the Paleoproterozoic Zaonega Formation, Russia: Documentation of 13C-depleted non-primary calcite. Precambrian Res 240, 79-93.

Ernst, R.E., Buchan, K.L., 2001. Large mafic magmatic events through time and links to mantle-plume heads. Geological Society of America Special Papers 352, 483-575.

Gancarz, A.J., 1978. U-Pb age (2.05 x 10^9 years) of the Oklo uranium deposit, Les réacteurs de fission naturels. IAEA, Vienna, , pp. 513-520.

Gärtner, C., Bahlburg, H., Martin, A.P., Condon, D.J., Prave, A.R., Lepland, A., Berndt, J., Gerdes, A., 2011. Detrital zircon geochronology and provenance analysis for Paleoproterozoic siliciclastic sediments of the Fennoscandian Shield (extended abstract), IODP/ICDP Kolloquium, Münster, 14-16 March 2011, pp. 63-66.

Gärtner, C., Bahlburg, H., Melezhik, V.A., Berndt, J., 2014. Dating Palaeoproterozoic glacial deposits of the Fennoscandian Shield using detrital zircons from the Kola Peninsula, Russia. Precambrian Res 246, 281-295.

Gauthier-Lafaye, F., Weber, F., 2003. Natural nuclear fission reactors: time constraints for occurrence, and their relation to uranium and manganese deposits and to the evolution of the atmosphere. Precambrian Res 120, 81-100.

Hannah, J.L., Stein, H., Yang, G., Zimmerman, A., 2010. Paleoproterozoic pyrobitumen: Re-Os geochemistry reveals the fate of giant carbon accumulations in Russian Karelia, Fall meeting AGU, San Francisco.

Hannah, J.L., Stein, H., Yang, G., Zimmerman, A., Melezhik, V.A., Filippov, M., Turgeon, S.C., Creaser, R., 2008. Re-Os geochronology of a 2.05 Ga fossil oil field near Shunga, Karelia, NW Russia, 33rd International Geological Congress, Oslo.

Hannah, J.L., Stein, H.J., Zimmerman, A., Yang, G., Markey, R.J., Melezhik, V.A., 2006. Precise $2004 \pm$ $9 \mathrm{Ma} \mathrm{Re}-\mathrm{Os}$ age for Pechenga black shale: Comparison of sulfides and organic material. Geochim Cosmochim Acta 70, A228.

Hanski, E.J., Huhma, H., Melezhik, V.A., 2014. New isotopic and geochemical data from the Palaeoproterozoic Pechenga Greenstone Belt, NW Russia: Implication for basin development and duration of the volcanism. Precambrian Res 245, 51-65. 
Hanski, E.J., Huhma, H., Smol'kin, V.F., Vaasjoki, M., 1990. The age of ferropicritic volcanites and comagmatic Ni-bearing intrusions at Pechenga, Kola Peninsula, U.S.S.R. Geol Surv Finland Bull 62, 123-133.

Hermoso, M., Minoletti, F., Rickaby, R.E.M., Hesselbo, S.P., Baudin, F., Jenkyns, H.C., 2012. Dynamics of a stepped carbon-isotope excursion: Ultra high-resolution study of Early Toarcian environmental change. Earth Planet Sci Lett 319-320, 45-54.

Hoatson, D.M., Jaireth, S., Jaques, A.L., 2006. Nickel sulfide deposits in Australia: Characteristics, resources, and potential. Ore Geol Rev 29, 177-241.

Horie, K., Hidaka, H., Gauthier-Lafaye, F., 2005. U-Pb geochronology and geochemistry of zircon from the Franceville series at Bidoudouma, Gabon. Geochim Cosmochim Acta 68, A11.

Isley, A.E., Abbott, D.H., 1999. Plume-related mafic volcanism and the deposition of banded iron formation. Journal of Geophysical Research: Solid Earth 104, 15461-15477.

Jenkyns, H.C., 1988. The early Toarcian (Jurassic) anoxic event; stratigraphic, sedimentary and geochemical evidence. Am J Sci 288, 101-151.

Karhu, J.A., Holland, H.D., 1996. Carbon isotopes and the rise of atmospheric oxygen. Geology 24, 867-870.

Krupenik, V.A., Akhmedov, A.M., Sveshnikova, K.Y., 2011. Isotopic composition of carbon, oxygen and sulphur in the Ludicovian and Jatulian rocks, in: Glushanin, L.V., Sharov, N.V., Shchiptsov, V.V. (Eds.), Palaeoproterozoic Onega Structure (Geology, Tectonics, Deep Structure and Mineralogeny). Karelian Research Centre, Russian Academy of Sciences, Petrozavodsk, pp. 250-255 (in Russian).

Kump, L.R., Junium, C., Arthur, M.A., Brasier, A., Fallick, A., Melezhik, V., Lepland, A., CČrne, A.E., Luo, G., 2011. Isotopic Evidence for Massive Oxidation of Organic Matter Following the Great Oxidation Event. Science 334, 1694-1696.

Lepland, A., Joosu, L., Kirsimae, K., Prave, A.R., Romashkin, A.E., Crne, A.E., Martin, A.P., Fallick, A.E., Somelar, P., Upraus, K., Mand, K., Roberts, N.M.W., van Zuilen, M.A., Wirth, R., Schreiber, A., 2014. Potential influence of sulphur bacteria on Palaeoproterozoic phosphogenesis. Nature Geosci 7, 20-24.

Martin, A.P., Condon, D.J., Prave, A.R., Lepland, A., 2013a. A review of temporal constraints for the Palaeoproterozoic large, positive carbonate carbon isotope excursion (the Lomagundi-Jatuli Event). Earth Sci Rev 127, 242-261.

Martin, A.P., Condon, D.J., Prave, A.R., Melezhik, V.A., Lepland, A., Fallick, A.E., 2013b. Dating the termination of the Palaeoproterozoic Lomagundi-Jatuli carbon isotopic event in the North Transfennoscandian Greenstone Belt. Precambrian Res 224, 160-168.

Melezhik, V., Prave, A., Fallick, A., Kump, L., Strauss, H., Lepland, A., Hanski, E., 2013. Reading the Archive of Earth's Oxygenation. Springer, Heidelberg.

Melezhik, V.A., Fallick, A.E., Filippov, M.M., Larsen, O., 1999. Karelian shungite-an indication of 2.0Ga-old metamorphosed oil-shale and generation of petroleum: geology, lithology and geochemistry. Earth Sci Rev 47, 1-40.

Melezhik, V.A., Huhma, H., Condon, D.J., Fallick, A.E., Whitehouse, M.J., 2007. Temporal constraints on the Paleoproterozoic Lomagundi-Jatuli carbon isotopic event. Geology 35, 655-658.

Needham, R.S., Stuart-Smith, P.G., Page, R.W., 1988. Tectonic evolution of the Pine Creek Inlier, Northern Territory. Precambrian Res 40-41, 543-564.

Negrutsa, V.Z., 1963. Experience in the sedimentological study of Proterozoic (Jatulian) formations of Central Karelia. Soviet Geology 7, 52-76 (in Russian).

Ovchinnikova, G.V., Kuznetsov, A.B., Melezhik, V.A., Gorokhov, I.M., Vasil'eva, I.M., Gorokhovskii, B.M., 2007. Pb-Pb age of Jatulian carbonate rocks: The Tulomozero Formation of southeast Karelia. Stratigr Geol Correl 15, 359-372.

Papineau, D., 2010. Global biogeochemical changes at both ends of the proterozoic: insights from phosphorites. Astrobiology 10, 165-181. 
Préat, A., Bouton, P., Thiéblemont, D., Prian, J.-P., Ndounze, S.S., Delpomdor, F., 2011. Paleoproterozoic high $\delta^{13} \mathrm{C}$ dolomites from the Lastoursville and Franceville basins (SE Gabon): Stratigraphic and synsedimentary subsidence implications. Precambrian Res 189, 212-228.

Priyatkina, N., Khudoley, A.K., Ustinov, V.N., Kullerud, K., 2014. 1.92 Ga kimberlitic rocks from Kimozero, NW Russia: Their geochemistry, tectonic setting and unusual field occurrence. Precambrian Res 249, 162-179.

Puchtel, I.S., Brugmann, G.E., Hofmann, A.W., 1999. Precise Re-Os mineral isochron and Pb-Nd-Os isotope systematics of a mafic-ultramafic sill in the $2.0 \mathrm{Ga}$ Onega plateau (Baltic Shield). Earth Planet Sci Lett 170, 447-461.

Puchtel, L.S., Arndt, N.T., Hofmann, A.W., Haase, K.M., Kroener, A., Kulikov, V.S., Kulikova, V.V., Garbe-Schoenberg, C.D., Nemchin, A.A., 1998. Petrology of mafic lavas within the Onega Plateau, central Karelia: evidence for $2.0 \mathrm{Ga}$ plume-related continental crustal growth in the Baltic Shield. Contrib Mineral Petrol 130, 134-153.

Qu, Y., Črne, A.E., Lepland, A., van Zuilen, M.A., 2012. Methanotrophy in a Paleoproterozoic oil field ecosystem, Zaonega Formation, Karelia, Russia. Geobiology 10, 467-478.

Sivaev, V.V., Goroshko, A.F., Gorbatyuk, L.V., 1982. Report on a 1:50,000 Geological Mapping and Investigation of the North-Western Limb of the Onega Depression and its Surroundings Conducted in 1978-1982. CSPGO, KKGRE, Petrozavodsk, p. 424 (in Russian).

Skuf'in, P.K., Bayanova, T.B., 2006. Early proterozoic central-type volcano in the Pechenga structure and its relation to the ore-bearing gabbro-wehrlite complex of the Kola Peninsula. Petrology 14, 609-627.

Stepanova, A.V., Samsonov, A.V., Larionov, A.N., 2014. The final episode of middle Proterozoic Magmatism in the Onega Structure: Data on trans-Onega dolerites. Proceedings of the Karelian Research Centre of the Russian Academy of Sciences. Precambrian Geology Series 1, 3-16.

Tejada, M.L.G., Suzuki, K., Kuroda, J., Coccioni, R., Mahoney, J.J., Ohkouchi, N., Sakamoto, T., Tatsumi, Y., 2009. Ontong Java Plateau eruption as a trigger for the early Aptian oceanic anoxic event. Geology 37, 855-858.

Walker, R.J., Morgan, J.W., Hanski, E., Smolkin, V.F., 1997. Re-Os systematics of early Proterozoic ferropicrites, Pechenga Complex, NW Russia: evidence for ancient ${ }^{187}$ Os-enriched plumes. Geochim Cosmochim Acta 61, 3145-3160.

Weber, F., Gauthier-Lafaye, F., 2013. No proof from carbon isotopes in the Francevillian (Gabon) and Onega (Fennoscandian shield) basins of a global oxidation event at 1980-2090 Ma following the Great Oxidation Event (GOE). CR Geosci 345, 28-35.

White, J.D.L., Houghton, B.F., 2006. Primary Volcaniclastic Rocks. Geology 34, 677-680.

Worden, K., Carson, C., Scrimgeour, I., Lally, J., Doyle, N., 2008. A revised Palaeoproterozoic chronostratigraphy for the Pine Creek Orogen, northern Australia: Evidence from SHRIMP U$\mathrm{Pb}$ zircon geochronology. Precambrian Res 166, 122-144.

Young, G.M., 2004. Earth's earliest extensive glaciations: Tectonic setting and stratigraphic context of Paleoproterozoic glaciogenic deposits, The Extreme Proterozoic: Geology, Geochemistry, and Climate. AGU, Washington, DC, pp. 161-181. 


\section{Highlights}

- Palaeoproterozoic carbon burial episodes (CBE) \& excursions are temporally discrete

- Zircon ID-TIMS yields Russian CBE ages at c. 1.97 (Onega) and c. 1.92 Ga (Pechenga)

- Temporal relationship between Large Igneous Provinces and CBE

- Similarities noted between Palaeoproterozoic CBE and Mesozoic Ocean Anoxic Events

- We suggest biogeochemical processes analogous to modern ones post the GOE 


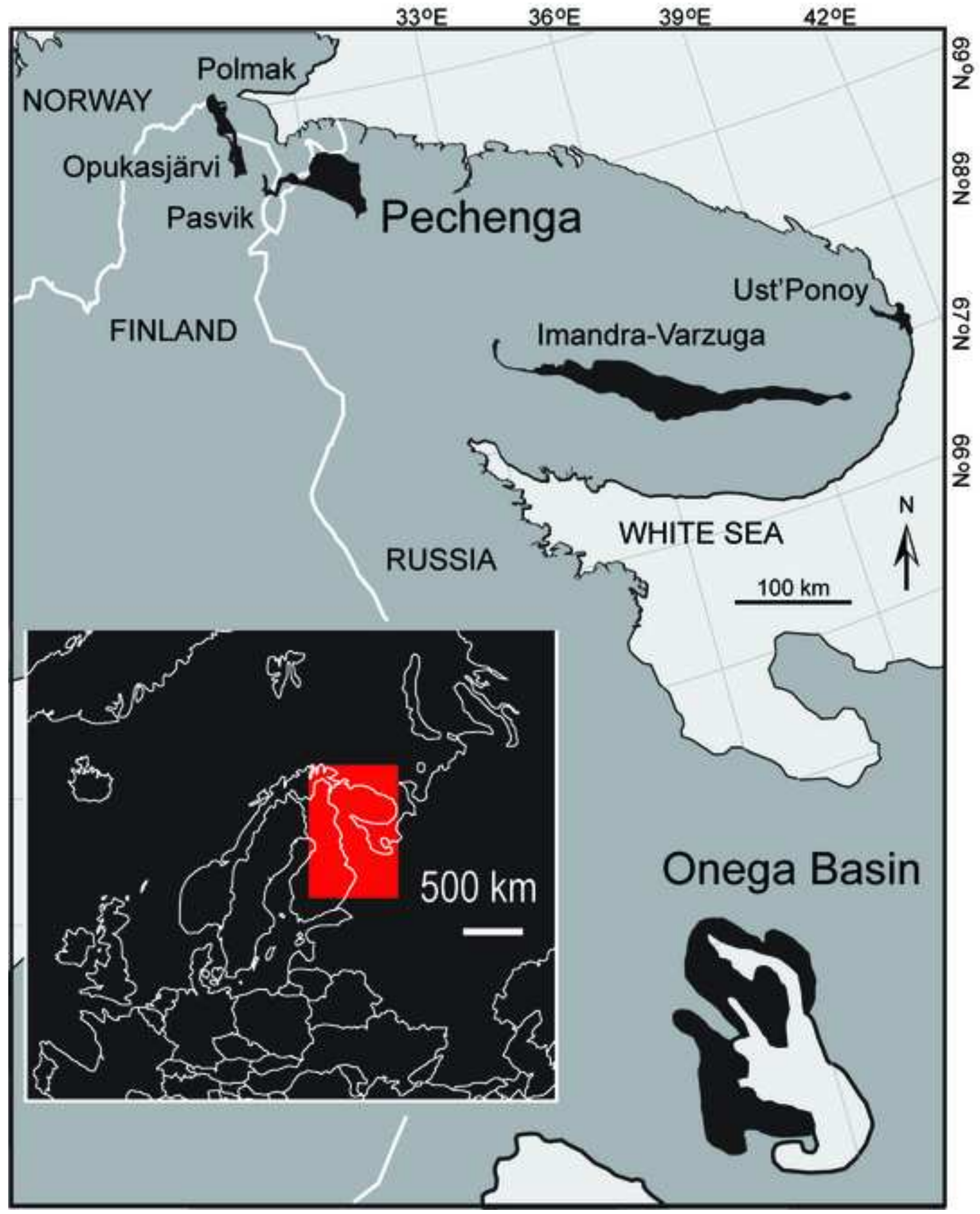




\section{Figure3}

Click here to downl@्वृd Figure: Fig. 3 Onega Strat.eps

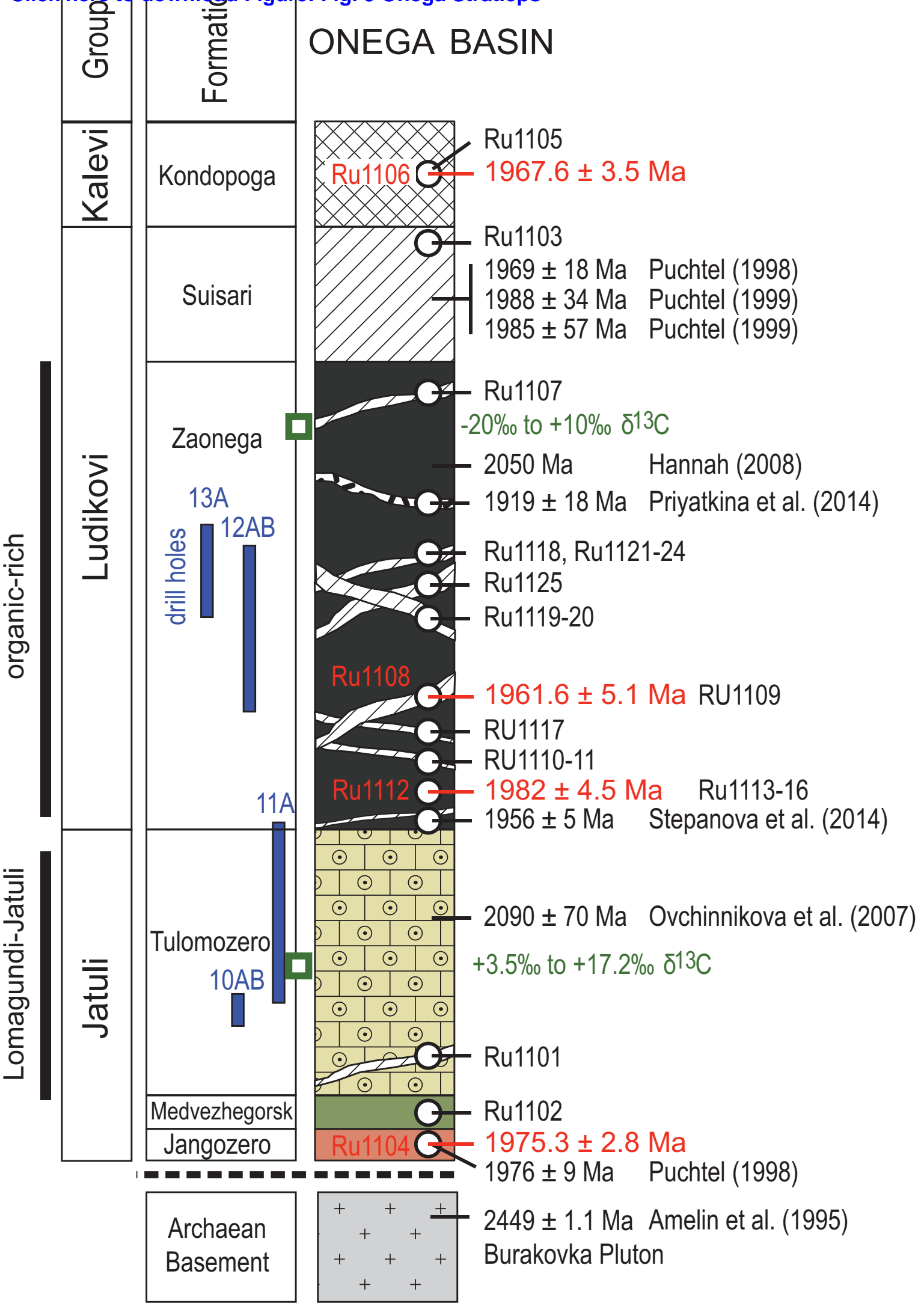

Xiliciclastic sedimentary rocks

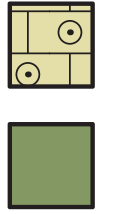

Carbonate rocks

Mafic

igneous rocks

Mafic - intermediate

igneous rocks

Organic-carbon-rich rocks (shungite)

Intermediate

igneous rocks 
Click here to download high resolution image
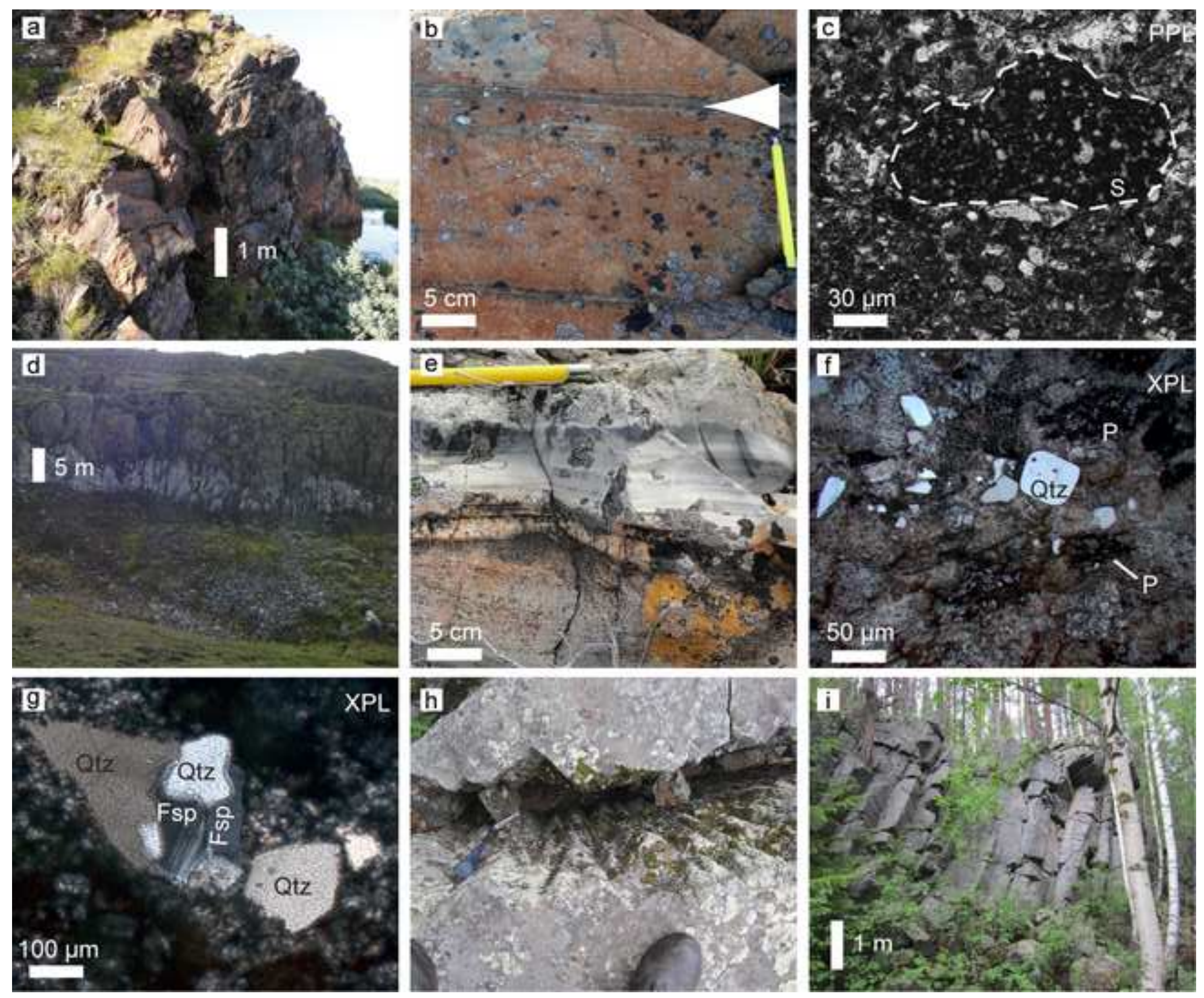
Pilgujärvi

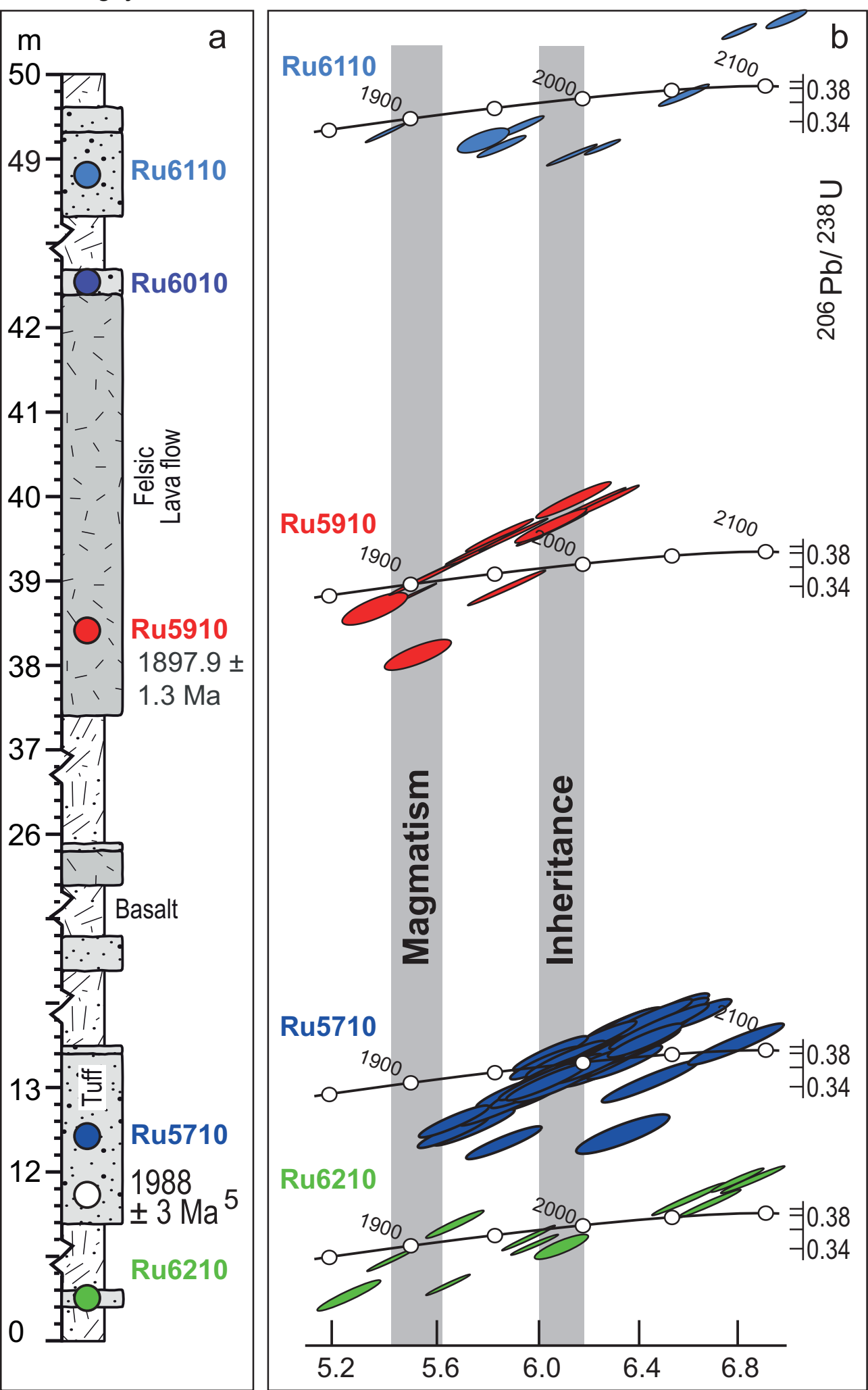

5 Hanski et al. (2014) - approximate position
ID-TIMS data

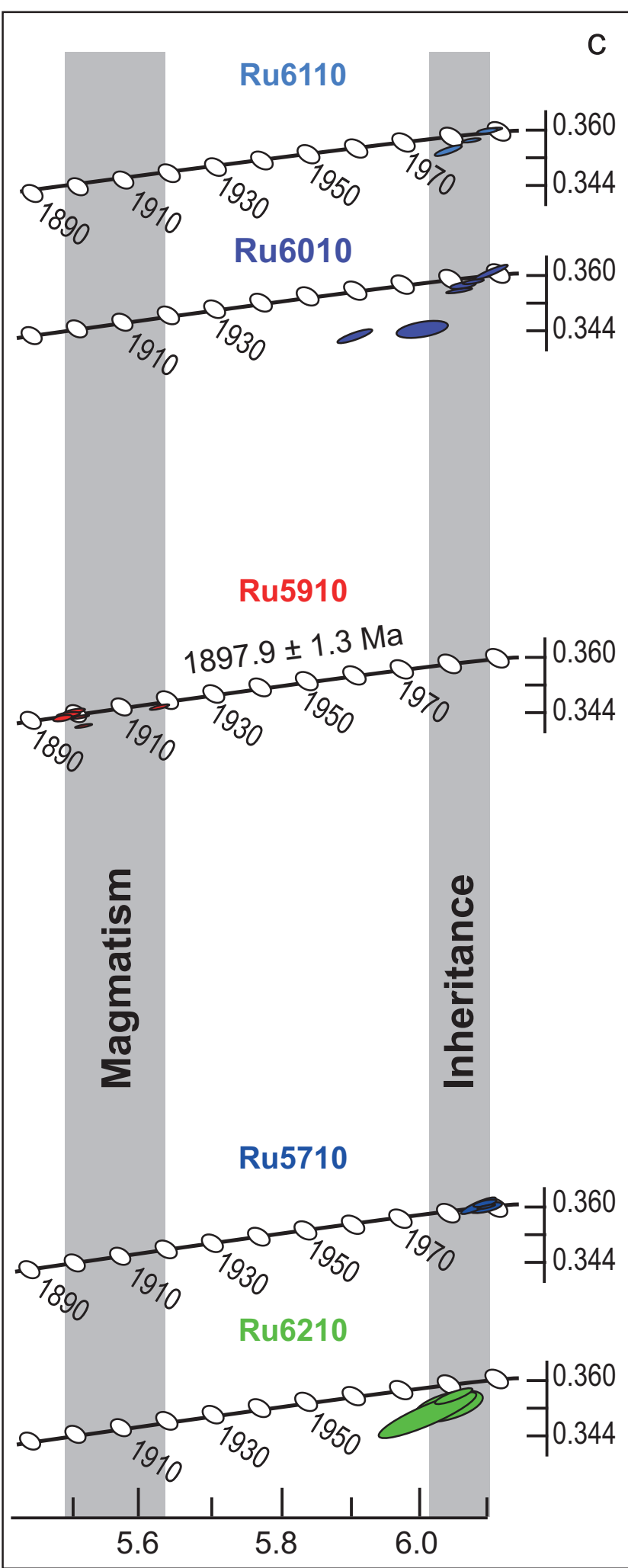

${ }^{207} \mathrm{~Pb} /{ }^{235} \mathrm{U}$ 


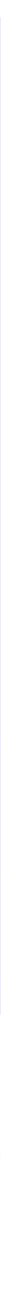




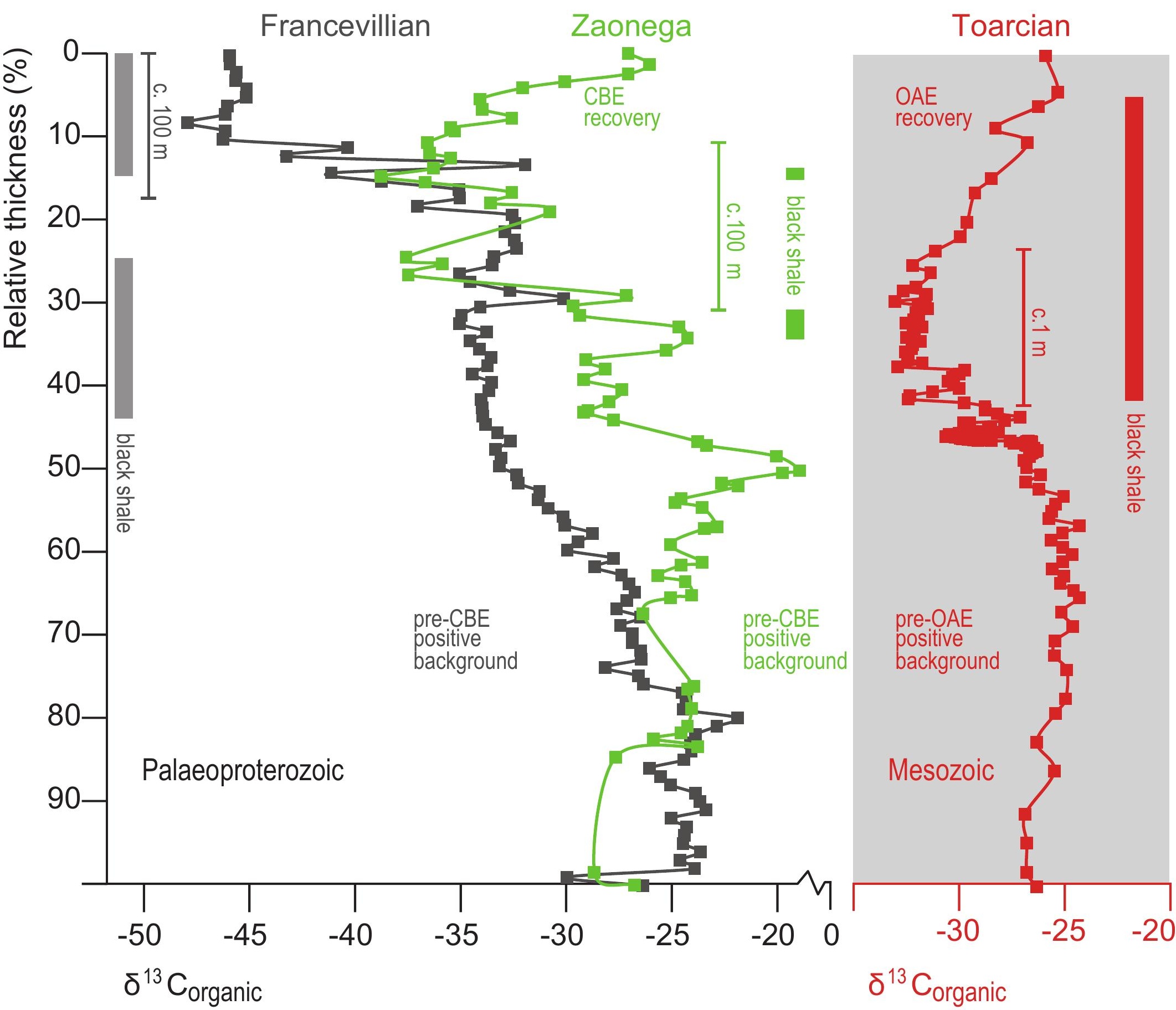



Supplementary material for online publication only
Click here to download Supplementary material for

Supplementary material for online publication only
Click here to download Supplementary material for online publication only: aMartin_etal_PalaeoCBE_Supp_EPSL_2.pdf 西 (a) (n) .

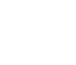
. . $x^{2}$ 